\title{
PENGARUH KUALITAS SUMBER DAYA MANUSIA DALAM MENINGKATKAN KINERJA TIM PENGELOLAH KEGIATAN PROGRAM NASIONAL PEMBERDAYAAN MASYARAKAT MANDIRI PEDESAAN (TPK PNPM-MP) PNPM-MP DI KECAMATAN MASAMBA KABUPATEN LUWU UTARA
}

\author{
Saharuddin ${ }^{1}$ \\ Budiman²
}

No. HP 0813425123791

\begin{abstract}
ABSTRAK
Tujuan penelitian adalah untuk mengetahui dan menganalisis Pengaruh Kualitas Sumber Daya Manusia dalam Meningkatkan Kinerja Tpk PNPM-Mpdi Kecamatan Masamba Kabupaten Luwu Utara. Penelitian yang dilakukan merupakan penelitian explanatory dan menggunakan metode survey. Populasi penelitian adalah Karyawan Pada Kantor PNPM-MP di Kecamatan Masamba Kabupaten Luwu Utara yang berjumlah 22 orang yang sekaligus dijadikan sebagai sampel dalam penelitian. Metode analisis data yang dipergunakan dalam penelitian ini adalah analisis deskriptif dan Regresi Sederhana, dimana variabel bebasnya terdiri dari Kualitas Sumber Daya Manusia dan untuk variabel dependen yaitu Kinerja Tpk PNPM-MP.

Hasil penelitian dengan menggunakan analisis regresi Sederhana menunjukkan bahwa secara simultan (Uji F) variabel Sumber Daya Manusia berpengaruh signifikan terhadap variabel Kinerja Karyawan Tpk PNPM-MP, sehingga hipotesis dalam penelitian ini yang menduga bahwa berpengaruh positif dan signifikan terhadap Kinerja Karyawan TPK Pada Kantor PNPM-MP di Kecamatan Masamba Kabupaten Luwu Utara terbukti kebenarannya. Sedangkan untuk (Uji-t) untuk variabel Kualitas Sumber Daya Manusia dapat ditunjukkan pada hasil perhitungan tabel dimana diketahui bahwa nilai thitung=3,024 pada taraf nyata $(p=0,007<@=0,05)$ atau thitung (3,024) >ttabel (2,086), maka HO ditolak dan Haditerima.Angka tersebut menunjukkan bahwa Kualitas Sumber Daya Manusia mempunyai pengaruh positif signifikan terhadap kinerja karyawan Tim Pengelola Kegiatan Program Nasional Pemberdayaan Masyarakat Mandiri Pedesaan (PNPM-MP) Kecamatan Masamba Kabupaten Luwu Utara dapat diterima

Kata Kunci: Kualitas Sumber Daya Manusia dan Kinerja Karyawan.
\end{abstract}

\section{PENDAHULUAN}

Sumber daya manusia adalah sumber daya organisasi selain sumber daya alam dan sumber daya modal. Manajemen sumber daya manusia harus diperhatikan, karena setiap manusia memiliki kreativitas, rasa dan inisiatif untuk membangun sikap, maka sikap inilah yang mendasari perilaku manusia dan tindakan manusia sehari-hari. Sumber daya manusia merupakan salah satu faktor yang paling penting, maka dapat kita lihat kenyataannya, ada perusahaan yang memiliki teknologi, prosedur kerja dan, struktur organisasi yang sama, tetapi manajemen suatu usaha yang satu dengan yang lain berbeda-beda.

Sumber daya manusia dalam suatu organisasi atau usaha sangat diperhatikan pengelolaannya dalam hubungan ini maka fungsi-fungsi operasional dari fungsi pengadaan dalam manajemen sumber daya manusia sejak dari penarikan pegawai atau karyawan, seleksi, penempatan dan seterusnya. keberhasilannya akan sangat menentukan bagi kesuksesan fungsi berikutnya, yaitu pengembangan. Oleh karena itu fungsi-fungsi tersebut harus 
menjadi perhatian yang sunguh-sungguh dengan perolehan yang spesifik. Demikian pula dengan penempatan tenaga kerja baru hendaknya diperhatikan juga spesifikasinya. Hal ini dimaksudkan agar tercapainya kualitas kerja karyawan mengacu pada kualitas sumber daya manusia. Kualitas sumber daya manusia mengacu pada pengetahuan, keterampilan dan kemampuan .

Sosialisasi dan penyebaran informasi dalam PNPM Mandiri Pedesaan merupakan upaya untuk memperkenalkan dan menyebarluaskan informasi mengenai program dan pelaksanaan PNPM Mandiri pedesaan kepada masyarakat. Upaya ini juga diharapkan menjadi media pembelajaran mengenai, konsep, prinsip, prosedur, kebijakan, tahapan pelaksanaan dan hasil pelaksanaan PNPM Mandiri Pedesaan Kepada Masyarakat luas. Hakekat pembangunan merupakan upaya yang dilakukan untuk meningkatkan kesejahteraan masyarakat. Dalam hal ini menempatkan arah pandang pembangunan sangat didasarkan pada paradigma yang mendasari para pengambil kebijakan disuatu negara yang diimplementasikan.

Perkembangan pembangunan di Indonesia lebih banyak dipengaruhi oleh teori pertumbuhan ekonomi yang memiliki resiko pada kesenjangan pembangunan antar daerah. Pembangunan dengan mengedepankan pertumbuhan ekonomi menjadi solusi untuk mengatasi permasalahan sosial dan politik yang dihadapi bangsa indonesia.
Program Nasional Pemberdayaan Masyarakat Mandiri (PNPM Mandiri) adalah program pemerintah untuk pengentasan kemiskinan dan penurunan tingkat pengangguran yang berbasis pada partisipasi dan pemberdayaan masyarakat. Hal ini dilatar belakangi bahwa masih terdapat kesenjangan antara pencapaian dan sasaran dalam meningkatkan kesejahteraan rakyat, yaitu angka kemiskinan dan pengangguran yang masih cukup besar. PNPM Mandiri merupakan integrasi dan perluasan programprogram penanggulangan kemiskinan yang berbasis masyarakat yang sudah dan sedang berjalan.

Masyarakat yang dimaksud adalah masyarakat penerima manfaat langsung kegiatan yakni Rumah Tangga Miskin, para pelaku program, instansi atau lembaga pendukung pelaksana PNPM Mandiri Pedesaan lainnya.

Hasil yang diharapkan dari proses sosialisasi dan penyebaran informasi adalah dimengerti dan dipahaminya konsep, prinsip prosedur, kebijakan dan tahapan pelaksanaan PNPM Mandiri Pedesaan secara utuh, khususnya masyarakat di lokasi program sebagai pelaku sekaligus sasaran penerima program, masyarakat umum, instansi atau lembaga lainnya. Dengan demikian upaya pelembagaan dan pengintegrasian prinsip serta prosedur program dalam masyarakat dan sistem pemerintahan regular, dapat berjalan optimal.

Guna mencapai pemahaman yang utuh tentang PNPM Mandiri Pedesaan 
dilokasi program, serta dalam rangka meningkatkan pengetahuan dan pemahaman masyarakat luas terhadap keberadaan program, maka dalam pelaksanaannya, proses sosialisasi dan penyebaran informasi ini harus dilakukan secara terpadu dan berkelanjutan dan didukung dengan sumber daya manusia yang kompeten. Untuk itu dengan adanya perubahan paradigma yang lebih mengedepankan fungsi pembangunan berfokus pada manusia diperlukan perubahan-perubahan mendasar, seperti masalah kebijakan, peraturan, dan akses masyarakat pada proses pengambilan keputusan.

\section{METODE PENELITIAN}

Penelitian ini dilakulkan di Kantor PNPM-MP di Kecamatan Masamba. Dalam penelitian ini populasinya adalah seluruh staf pelaksana Kantor PNPM-MP di Kecamatan Masamba yang berjumlah 22 orang yang sekaligus dijadikan sampel penelitian. Jenis dan sumber data yang digunakan yaitu data primer dan sekunder.

\section{Metode Analisis Data}

\section{Analisis Deskriptif}

Analisis deskriptif dimaksudkan untuk memberikan gambaran profil responden yang terpilih serta gambaran atau deskripsi suatu data. Profil responden yang terpola dapat membantu dalam memahami pengaruh kualitas sumber daya manusia terhadap kinerja TPK PNPM-MP di Kecamatan Masamba.

\section{Uji Validitas dan Reliabilitas}

Uji validitas dilakukan dengan membandingkan nilai masing-masing item dengan total skor. Uji validitas digunakan untuk mengukur sah atau valid tidaknya suatu kuisioner (Imam Ghozali, 2006 : 49). Uji validitas menggunakan rumus The Product Moment Coeffisient corelation yaitu dengan melihat $r_{\text {hitung }}$ masing-masing item pertanyaan dibandingkan dengan $r_{\text {tabel }}$ pada tingkat signifikan $5 \%$ dan $d f=n-2$, yaitu sebesa222 dengan menggunakan tabel Product Momentdiperoleh nilai $r_{\text {tabel }}$ sebesar0,422, maka apabila $r_{\text {hitung }}>r_{\text {tabel, }}$ maka item pertanyaan tersebut dinyatakan valid ( Santoso, 2004: 276 ).

Kemudian pengukuran reliabilitas dapat dilakukan dengan cara One Shot atau pengukuran sekali saja: Disini pengukurannya hanya sekali dan kemudian hasilnya dibandingkan dengan pertanyaan lain atau mengukur reliabilitas dengan uji statistikCronbach Alpha (á). Suatu konstruk atau variabel dikatakan reliabel jika memberikan nilai Cronbach Alpha>0,60, (Imam Ghozali, 2006: 46). Adapun hasil uji validitas dan reliabilitas instrument penelitian adalah sebagai berikut:

Uji validitas dan reliabilitas indikator Pengembangan Kualitas SDM dapat dilihat pada Tabel 1 berikut: 


\section{Tabel 1}

Uji Validitas dan Reliabilitas Kualitas Sumber Daya Manusia (X)

\begin{tabular}{|l|l|l|l|l|l|}
\hline \multirow{2}{*}{ No } & \multirow{2}{*}{$\begin{array}{l}\text { Item } \\
\text { Pertanyaan }\end{array}$} & $\begin{array}{l}\text { Uji Validitas } \\
\text { Koefisien } \\
\text { Korelasi }\end{array}$ & Kategori & $\begin{array}{l}\text { Cronbach } \\
\text { Alpha }\end{array}$ & Kategori \\
\hline 1 & P 1 & 0,434 & Valid & & \\
2 & P 2 & 0,472 & Valid & & \\
3 & P 3 & 0,724 & Valid & & \\
4 & SM 1 & 0,591 & Valid & \multirow{2}{*}{ Reliabel } \\
5 & SM 2 & 0,438 & Valid & 0,702 & \\
6 & SM 3 & 0,478 & Valid & & \\
\hline 7 & K1 & 0,584 & Valid & & \\
8 & K2 & 0,455 & Valid & & \\
9 & K3 & 0,677 & Valid & & \\
\hline
\end{tabular}

Sumber: Data Primer diolah 2014

Berdasarkan hasil uji validitas dan reliabilitas kualitas sumber daya manusia yang disajikan pada Tabel 1 menunjukkan bahwa nilai koefisien korelasi pada kolom uji validitas nilai koefisien korelasi dari 9indikator kualitas sumber daya manusia lebih besar dari batas minimal nilai ( $r$ tabel) yaitu 0,422.
Sedangkan untuk nilai Cronbach Alpha pada kolom uji reliabilitas adalah sebesar 0,702 lebih besar dari 0,60. Dengan demikian untuk9 indikator kualitas sumber daya manusia terkategori valid dan reliabel.

Uji validitas dan reliabilitas indikator Kinerja Karyawan dapat dilihat pada Tabel 2 berikut:

Tabel 2

\section{Uji Validitas dan Reliabilitas Kinerja Karyawan}

\begin{tabular}{|l|l|l|l|l|l|}
\hline \multirow{2}{*}{ No } & Item & Pertanyaan & \multicolumn{2}{|l|}{ Uji Validitas } & \multicolumn{2}{l|}{ Uji Reliabilitas } \\
\cline { 3 - 6 } & $\begin{array}{l}\text { Koefisien } \\
\text { Korelasi }\end{array}$ & Kategori & $\begin{array}{l}\text { Cronbach } \\
\text { Alpha }\end{array}$ & Kategori \\
\hline 1 & K 1 & 0,426 & Valid & & \\
2 & K2 & 0,430 & Valid & & \\
3 & PK1 & 0,579 & Valid & & Reliabel \\
\hline 4 & PK2 & 0,688 & Valid & 0,750 & \\
5 & KDSP1 & 0,646 & Valid & & \\
6 & KDSP 2 & 0,754 & Valid & & \\
7 & TJ 1 & 0,646 & Valid & & \\
8 & TJ2 & 0,621 & Valid & & \\
\hline
\end{tabular}


Berdasarkan hasil uji validitas dan reliabilitas kinerja karyawan yang disajikan pada Tabel 8 menunjukkan bahwa nilai koefisien korelasi pada kolom uji validitas nilai koefisien korelasi dari 20indikator kinerja karyawan lebih besar dari batas minimal nilai ( $r$ tabel) yaitu 0,228 . Sedangkan untuk nilai Cronbach Alpha pada kolom uji reliabilitas adalah sebesar 0,750 lebih besar dari 0,60. Dengan demikian untuk8 indikator kinerja pegawai terkategori valid dan reliabel.

\section{Analsis Regresi Sederhana}

Adapun metode analisis yang digunakan adalah menggunakan metode Analisis Regresi Sederhanadengan formulasi matematis sebagai berikut (Suliyanto,2011:39) :
$\mathrm{Y}=\mathrm{a}+\mathrm{bX}+\mathrm{e}$

Di mana :

$$
\begin{array}{ll}
\mathrm{Y} & =\text { Kinerja TPK PNPM-MP } \\
\mathrm{a} & =\text { Nilai intersepsi (konstanta) } \\
\mathrm{b} & =\text { Koefisien regresi } \\
\mathrm{X} & =\text { Kualitas SDM } \\
\mathrm{e} & =\text { error (tingkat kesalahan) }
\end{array}
$$

HASIL PENELITIAN DAN PEMBAHASAN

Statistik Deskriptif dan Metode
Pengujian Data

Statistik Deskriptif

\begin{tabular}{|c|c|c|c|c|c|c|c|c|c|c|c|c|}
\hline \multirow{3}{*}{ No } & \multirow{3}{*}{$\begin{array}{c}\text { Item } \\
\text { Pernyat } \\
\text { aan }\end{array}$} & \multicolumn{10}{|c|}{ tanggapan Responden } & \multirow{3}{*}{$\mathbf{N}$} \\
\hline & & \multicolumn{2}{|c|}{ SS (5) } & \multicolumn{2}{|c|}{$S(4)$} & \multicolumn{2}{|c|}{$\mathbf{R}(3)$} & \multicolumn{2}{|c|}{ KS (2) } & \multicolumn{2}{|c|}{ STS (1) } & \\
\hline & & $\bar{F}$ & $\%$ & $\bar{F}$ & $\%$ & $\mathbf{F}$ & $\%$ & $\bar{F}$ & $\%$ & $\bar{F}$ & $\%$ & \\
\hline 1 & $\mathrm{P} 1$ & 5 & 22,7 & 15 & 68,2 & 0 & 00,0 & 2 & 9,1 & 0 & 00,0 & 22 \\
\hline 2 & P 2 & 5 & 22,7 & 13 & 59,1 & 1 & 4,5 & 3 & 13,6 & 0 & 00,0 & 22 \\
\hline 3 & P 3 & 9 & 40,9 & 10 & 45,5 & 2 & 9,1 & 1 & 4,5 & 0 & 00,0 & 22 \\
\hline 4 & SM 1 & 4 & 18,2 & 18 & 81,8 & 0 & 00,0 & 0 & 00,0 & 0 & 00,0 & 22 \\
\hline 5 & SM 2 & 5 & 22,7 & 13 & 59,1 & 3 & 13,6 & 1 & 4,5 & 0 & 00,0 & 22 \\
\hline 6 & SM 3 & 6 & 27,3 & 13 & 59,1 & 3 & 13,6 & 0 & 00,0 & 0 & 00,0 & 22 \\
\hline 7 & KT 1 & 7 & 31,8 & 10 & 45,5 & 2 & 9,1 & 3 & 13,6 & 0 & 00,0 & 22 \\
\hline 8 & KT 2 & 7 & 31,8 & 12 & 54,5 & 3 & 13,6 & 0 & 00,0 & 0 & 00,0 & 22 \\
\hline 9 & KT 3 & 14 & 63,2 & 8 & 36,4 & 0 & 00,0 & 0 & 00,0 & 0 & 00,0 & 22 \\
\hline
\end{tabular}

Variabel Kualitas Sumber Daya Manusia

Tabel 3

Tanggapan Respoden Terhadap Variabel Kualitas Sumber Daya Manusia 
Berdasarkan tabel 5 diatas dapat dideskripsikan tanggapan responden terhadap item-item variabel kualitas sumber daya manusia sebagai berikut:

1. Tanggapan responden terhadap pernyataan (P1) "Tingkat pendidikan anda saat ini berpengaruh terhadap pengetahuan anda dalam menyelesaikan setiap tugas/pekerjaan" sebagian besar responden menyatakan setuju $(68,2 \%)$.

2. Tanggapan responden terhadap pernyataan (P2) "Karyawan yang memiliki tingkat pengetahuan dan pendidikan yang tinggi mampu menguasai bagaimana menerapkan teknologi dan informasi dalam menyelesaikan setiap pekerjaan" sebagian besar responden menyatakan setuju $(59,1 \%)$.

3. Tanggapan responden terhadap $\begin{array}{lll}\text { pernyataan } & \text { (P3) "Tingkat }\end{array}$ pengetahuan/pendidikan anda saat ini membuat anda lebih mudah dan luwes dalam berkomunikasi dengan sesama staf pegawai maupun masyarakat" sebagian besar responden menyatakan setuju $(45,5 \%)$.
4. Tanggapan responden terhadap pernyataan (SM1) "Anda merasa senang dan tidak tertekan dengan pekerjaan anda saat ini" sebagian besar responden menyatakan setuju $(81,8 \%)$.

5. Tanggapan responden terhadap pernyataan (SM2) "Setiap pekerjaan yang diberikan oleh pimpinan merupakan tantangan untuk kemajuan anda kedepannya" sebagian besar responden menyatakan setuju $(59,1 \%)$.

6. Tanggapan responden terhadap pernyataan (SM3) "Sikap mental yang anda miliki saat ini sangat mendukung anda dalam menyelesaikan pekerjaan anda" sebagian besar responden menyatakan setuju $(59,1 \%)$.

7. Tanggapan responden terhadap pernyataan (KT1) "Keterampilan yang anda miliki saat ini dapat membantu anda dalam menyelesaikan setiap pekrajaan yang diberikan oleh pimpinan anda" sebagian besar responden menyatakan setuju $(45,5 \%)$.

8. Tanggapan responden terhadap pernyataan (KT2) "Keterampilan dasar merupakan keterampilan seseorang yang 
pasti dan wajib dimiliki oleh kebanyakan orang" sebagian besar responden menyatakan setuju (54,5\%).

9. Tanggapan responden terhadap pernyataan (KT3) "Anda diberikan kesempatan untuk mengikuti pelatihan untuk menambah dan meningkatkan keterampilan anda khususnya dalam menyelesaikan pekerjaan" sebagian besar responden menyatakan sangat setuju $(63,2 \%)$

Secara umum variabel kepuasan kerja termasuk dalam kategori Setuju. Kondisi ini didukung dengan nilai modus atau yang sering muncul (dijawab oleh responden) pada lampiran 3 yaitu angka 4 (setuju). Artinya bahwa, karyawan TPK PNPM-MP Kecamatan Masamba Kabupaten Luwu Utara memiliki peluang untuk meningkatkan kinerja kepada setiap karyawannya.

\section{Variabel Kinerja Karyawan}

Dalam mendiskripsikan variabel kinerja karyawan maka dapat dilihat padafrekuensi hasil tanggapan responden terhadap masing-masing pertanyaan atau item yang digunakan untuk mengukur kinerja karyawan dan hasilnya terdapat dalam tabel 4 berikut ini:

Tabel 3

Tanggapan Respoden Terhadap Variabel Kualitas Sumber Daya Manusia

\begin{tabular}{|c|c|c|c|c|c|c|c|c|c|c|c|c|}
\hline \multirow{3}{*}{ No } & \multirow{3}{*}{$\begin{array}{c}\text { Item } \\
\text { Pernyataa } \\
\text { n }\end{array}$} & \multicolumn{10}{|c|}{ tanggapan Responden } & \multirow{3}{*}{$\mathbf{N}$} \\
\hline & & \multicolumn{2}{|c|}{ SS (5) } & \multicolumn{2}{|c|}{ S (4) } & \multicolumn{2}{|c|}{$\mathrm{R}(3)$} & \multicolumn{2}{|c|}{ KS (2) } & \multicolumn{2}{|c|}{ STS (1) } & \\
\hline & & $\bar{f}$ & $\%$ & $\bar{F}$ & $\%$ & $\mathbf{F}$ & $\%$ & $\mathbf{F}$ & $\%$ & $\mathbf{F}$ & $\%$ & \\
\hline 1 & $\mathrm{~K} 1$ & $\overline{3}$ & 13,6 & $\overline{14}$ & 63,6 & 4 & 18,2 & 1 & 4,5 & $\overline{0}$ & 00.0 & 22 \\
\hline 2 & K2 & 1 & 4,5 & 18 & 81,8 & 3 & 13,6 & 0 & 00.0 & 0 & 00.0 & 22 \\
\hline 3 & PK 1 & 7 & $\overline{31,8}$ & $\overline{12}$ & 54,5 & 1 & 4,5 & 2 & $\overline{9,1}$ & 0 & 00.0 & 22 \\
\hline 4 & PK 2 & 2 & 9,1 & 16 & 72,7 & 2 & 9,1 & 2 & 9,1 & 0 & 00.0 & 22 \\
\hline 5 & KDSP 1 & 7 & 31,8 & 14 & 63,6 & 1 & 4,5 & 0 & 00.0 & 0 & 00.0 & 22 \\
\hline 6 & KDSP2 & 3 & 13,6 & 15 & 68,2 & 2 & 9,1 & 2 & 9,1 & 0 & 00.0 & 22 \\
\hline 7 & TJ1 & 6 & 27,3 & 10 & 45,5 & 4 & 18,2 & 2 & 9,1 & 0 & 00.0 & 22 \\
\hline 8 & TJ 2 & 4 & 18,2 & 14 & 63,6 & 3 & 13,6 & 1 & 4,5 & 0 & 00.0 & 22 \\
\hline
\end{tabular}


Berdasarkan tabel 6 diatas dapat

dideskripsikan tanggapan responden

terhadap item-item variabel kinerja karyawan sebagai berikut:

1. Tanggapan responden terhadap pernyataan (K1) "Bapak/lbu memiliki loyalitas kepada atasan" sebagian besar responden menyatakan setuju (63,6\%).

2. Tanggapan responden terhadap pernyataan (K2) "Bapak/lbu memiliki loyalitas kepada organisasi" sebagian besar responden menyatakan setuju $(81,8 \%)$.

3. Tanggapan responden terhadap pernyataan (PK1) "Pekerjaan selalu diselesaikan oleh Bapak/lbu dengan tuntas dan memadai sehingga memiliki kualitas yang dapat diandalkan." sebagian besar responden menyatakan setuju $(54,5 \%)$.

4. Tanggapan responden terhadap pernyataan (PK2) "Volume kerja yang dihasilkan oleh Bapak/lbu dalam kondisi yang sesuai dengan batas waktu dan jadwal yang telah ditentukan yang terlihat dari SOP (Standard Operating Procedure)" sebagian besar responden menyatakan setuju (72,7\%).

5. Tanggapan responden terhadap pernyataan (KDSP1) "Bapak/lbu selalu taat pada peraturan yang berlaku di dalam organisasi" sebagian besar responden menyatakan setuju $(63,6 \%)$.

6. Tanggapan responden terhadap pernyataan (KDSP2) "Ketepatan waktu dan kehadiran" sebagian besar responden menyatakan setuju $(68,2 \%)$.

7. Tanggapan responden terhadap pernyataan (TJ1) "Bapak/lbu menyelesaikan pekerjaan sampai tuntas tanpa adanya penundaan" sebagian besar responden menyatakan sangat setuju $(45,5 \%)$.

8. Tanggapan responden terhadap pernyataan (TJ2) "Bapak/lbu berani memikul resiko pekerjaan yang dilakukan, baik itu yang berupa kesalahan administratif maupun dalam bentuk material" sebagian besar responden menyatakan setuju $(63,6 \%)$.

Secara umum variabel kinerja karyawan termasuk dalam kategori Setuju. Kondisi ini didukung dengan nilai modus atau yang sering muncul (dijawab oleh responden) pada lampiran 3 yaitu nilai 4 (setuju). Artinya bahwa, karyawan TPK PNPM-MP Kecamatan Masamba Kabupaten Luwu Utara memiliki peluang untuk meningkatkan kualitas sumber daya manusianya kepada karyawannya dalam meningkatkan kinerjanya.

Informasi ini belum cukup dapat menggali bagaimana hubungan antar variabel, sehingga masih diperlukan analisis lanjutan yaitu analisis regresi sederhana untuk menjelaskan ga $40 \mathrm{n}$ pengaruh dari variabel bebas terhadap variabel terikatnya. Terlebih dahulu dilakukan uji validitas data, dan uji reliabilitas data. 


\section{Uji Validitas dan Uji Reliabilitas}

Uji validitas dan reliabilitas digunakan untuk meyakinkan bahwa data dalam penelitian ini adalah valid dan dapat dipercaya serta untuk mengetahui tingkat kepercayaan terhadap alat ukur. Pengujian validitas dan reliabilitas instrument penelitian dilakukan melalui program SPSS versi 21 dengan melihat koefisien korelasi dan nilai Cronbach Alpha instrument.

Uji validitas dilakukan dengan membandingkan nilai masing-masing item dengan total skor. Uji validitas digunakan untuk mengukur sah atau valid tidaknya suatu kuisioner (Imam Ghozali, 2006 : 49). Uji validitas menggunakan rumus The Product Moment Coeffisient corelation yaitu dengan melihat $r_{\text {hitung }}$ masing-masing item pertanyaan dibandingkan dengan $r_{\text {tabel }}$ pada tingkat - signifikan $5 \%$ dan df $=n-2$, yaitu sebesa222 dengan menggunakan tabel Product Momentdiperoleh nilai $r_{\text {tabel }}$ sebesar0,422, maka apabila $r_{\text {hitung }}>r_{\text {tabel, }}$ maka item pertanyaan tersebut dinyatakan valid Santoso, 2004: 276 ).

Kemudian pengukuran reliabilitas dapat dilakukan dengan cara One Shot atau pengukuran sekali saja: Disini pengukurannya hanya sekali dan kemudian hasilnya dibandingkan dengan pertanyaan lain atau mengukur reliabilitas dengan uji statistikCronbach Alpha (á). Suatu konstruk atau variabel dikatakan reliabel jika memberikan nilai Cronbach Alpha>0,60, (Imam Ghozali, 2006: 46). Adapun hasil uji validitas dan reliabilitas instrument penelitian adalah sebagai berikut:

a. Uji validitas dan reliabilitas indikator Pengembangan Kualitas SDM dapat dilihat pada Tabel 4 berikut:

Tabel 4

\section{Uji Validitas dan Reliabilitas Kualitas Sumber Daya Manusia (X)}

\begin{tabular}{|c|c|c|c|c|c|}
\hline \multirow[b]{2}{*}{ No } & \multirow{2}{*}{$\begin{array}{c}\text { Item } \\
\text { Pertanyaan }\end{array}$} & \multicolumn{2}{|c|}{ Uji Validitas } & \multicolumn{2}{|c|}{ Uji Reliabilitas } \\
\hline & & $\begin{array}{c}\text { Koefisien } \\
\text { Korelasi }\end{array}$ & Kategori & $\begin{array}{c}\text { Cronbach } \\
\text { Alpha }\end{array}$ & Kategori \\
\hline 1 & P 1 & 0,434 & Valid & & \\
\hline 2 & P 2 & 0,472 & Valid & & \\
\hline 3 & P 3 & 0,724 & Valid & & \\
\hline 4 & SM 1 & 0,591 & Valid & & \\
\hline 5 & SM 2 & 0,438 & Valid & 0,702 & Reliabel \\
\hline 6 & SM 3 & 0,478 & Valid & & \\
\hline 7 & K1 & 0,584 & Valid & & \\
\hline 8 & $\mathrm{~K} 2$ & 0,455 & Valid & & \\
\hline 9 & K3 & 0,677 & Valid & & \\
\hline
\end{tabular}


Berdasarkan hasil uji validitas dan reliabilitas kualitas sumber daya manusia yang disajikan pada Tabel 7 menunjukkan bahwa nilai koefisien korelasi pada kolom uji validitas nilai koefisien korelasi dari 9indikator kualitas sumber daya manusia lebih besar dari batas minimal nilai ( $r$ tabel) yaitu 0,422.
Sedangkan untuk nilai Cronbach Alpha pada kolom uji reliabilitas adalah sebesar 0,702 lebih besar dari 0,60. Dengan demikian untuk9 indikator kualitas sumber daya manusia terkategori valid dan reliabel.

b. Uji validitas dan reliabilitas indikator Kinerja Karyawan dapat dilihat pada Tabel 8 berikut:

Tabel 5

Uji Validitas dan Reliabilitas Kinerja Karyawan

\begin{tabular}{|c|c|c|c|c|c|}
\hline \multirow[b]{2}{*}{ No } & \multirow{2}{*}{$\begin{array}{c}\text { Item } \\
\text { Pertanyaan }\end{array}$} & \multicolumn{2}{|c|}{ Uji Validitas } & \multicolumn{2}{|c|}{ Uji Reliabilitas } \\
\hline & & $\begin{array}{c}\text { Koefisien } \\
\text { Korelasi }\end{array}$ & Kategori & $\begin{array}{c}\text { Cronbach } \\
\text { Alpha }\end{array}$ & Kategori \\
\hline 1 & K 1 & 0,426 & Valid & & \\
\hline 2 & $\mathrm{~K} 2$ & 0,430 & Valid & & \\
\hline 3 & PK1 & 0,579 & Valid & & \\
\hline 4 & PK2 & 0,688 & Valid & 0750 & Boliahol \\
\hline 5 & KDSP1 & 0,646 & Valid & 0,150 & nellavel \\
\hline 6 & KDSP 2 & 0,754 & Valid & & \\
\hline 7 & TJ 1 & 0,646 & Valid & & \\
\hline 8 & TJ 2 & 0,621 & Valid & & \\
\hline
\end{tabular}

Berdasarkan hasil uji validitas dan reliabilitas kinerja karyawanyang disajikan pada Tabel 8 menunjukkan bahwa nilai koefisien korelasi pada kolom uji validitas nilai koefisien korelasi dari 20indikator kinerja karyawan lebih besar dari batas minimal nilai ( $r$ tabel) yaitu 0,228 . Sedangkan untuk nilai Cronbach Alpha pada kolom uji reliabilitas adalah sebesar 0,750 lebih besar dari 0,60. Dengan demikian untuk8 indikator kinerja pegawai terkategori valid dan reliabel.

\section{Analisis Regresi Linear Sederhana}

Variabel yang diduga berpengaruh terhadap kinerja karyawan TPK PNPM-MP
Kecamatan Masamba Kabupaten Luwu Utara adalah pengembangan kualitas SDM.Oleh karena itu perlu dilakukan uji hipotesis menggunakan analisis statistik yaitu analisis regresi sederhana. Dengan menggunakan program SPSS 21.00 didapat model regresi sebagai berikut:

$$
Y=b 0+\beta X+e
$$

Pada pengujian hopotesis yang diajukan, maka analisis linear berganda menghasilkan data tabel 6 sebagai berikut: 
Tabel 6

Hasil Analisis Regresi Sederhana

\begin{tabular}{|l|l|l|l|l|}
\hline \multicolumn{1}{|c|}{ Variabel } & Koef. Regresi & \multicolumn{1}{|c|}{$t_{\text {hitung }}$} & \multicolumn{1}{c|}{ Sig. } & Kesimpulan \\
\hline Konstanta & 10,704 & 1,537 & 0,140 & \\
Kualitas Sumber Daya Manusia & 0,560 & 3,024 & 0,007 & Signifikan \\
\hline Multiple R & $=0,560$ & F hitung $=0,144$ \\
R square & $=0,314$ & Sig. & $=0,007$ \\
Adjusted $R$ Square & $=0,279$ & & & \\
\hline
\end{tabular}

Berdasarkan tabel 9 diatas hasil pengujian yang dilakukan terhadap variabel kualitas sumber daya manusia maka dapat dirumuskan persamaan regresinya sebagai berikut:

$Y=10,704+0,560$ Kualitas Sumber Daya Manusia

Dengan menggunakan persamaan regresi pada model regresi berganda diatas maka dapat diuraikan sebagai berikut:

a. Nilai konstan sebesar 10,704 menunjukkan bahwa jika variabel bebas yaitu kualitas sumber daya manusiatidak mengalami perubahan atau sama dengan nol, maka nilai kinerja karyawan TPK PNPM-MP Kecamatan Masamba Kabupaten Luwu Utaraakan mengalami peningkatan sebesar 10,704.

b. Nilai koefisien regresi variabel pengembangan kualitas SDM sebesar 0,560 bernilai positif mempunyai arti bahwa jika pengembangan kualitas SDM naik sebesar satu satuan maka akan meningkatkankinerja karyawan sebesar 0,560 atau jika persepsi terhadap kualita sumber daya manusiasemakin baik maka itu akan meningkatkankinerja karyawan.

\section{Koefisien Korelasi dan Determinasi}

Dari hasil analisis regresi sebagaimana terlihat pada tabel 9 diperoleh nilai koefisien korelasi berganda sebesar 0,560. Korelasi atau hubungan antara variabel kualitas sumber daya manusia dengan kinerja karyawan adalah sebesar $56,00 \%$. Artinya koefisien korelasi yang bernilai positif tersebut menunjukkan orientasi hubungan searah, dimana kualitas sumber daya manusia semakin baik, maka akan meningkatkan kinerja karyawan.

Selanjutnya guna mengetahui seberapa besar sumbangan atau kontribusi dari variabel bebas terhadap variabel terikat.Koefisien determinasi ini ditentukan dengan mengkuadratkan nilai koefisien korelasi dan dikalikan dengan $100 \%$ untuk mendapatkan prosentase. Nilai koefisien determinasi $\left(\mathrm{R}^{2}\right)$ pada tabel 7 diperoleh angkasebesar 0,314, hal ini berarti bahwa $31,4 \%$ variasi dari naik turunya kinerja 
karyawan dapat dijelaskan olehkuaitas sumber daya manusia. Sedangkan sisanya sebesar $68,6 \%$ dipengaruhi oleh variabel lain yang tidak teranalisis dalam penelitian ini.

\section{Pengujian Hipotesis koefisien Regresi Motivasi Secara Parsial (Uji-t)}

Uji t ini digunakan untuk mengetahui ada atau tidaknya pengaruh antara kualitas sumber daya manusia terhadap kinerja karyawan pada TPK PNPM-MP Kecamatan Masamba Kabupaten Luwu Utara.

Perumusan hipotesis:

Ho: $\beta<0$ : tidak ada pengaruh yang positif dan signifikan kualitas sumber daya manusia terhadap kinerja karyawan pada TPK PNPM-MP Kecamatan Masamba Kabupaten Luwu Utara.

$\mathrm{Ha}: \beta>0$ : ada pengaruh yang positif dan signifikan kualitas sumber daya manusia terhadap kinerja karyawan pada TPK PNPM-MP Kecamatan

Masamba Kabupaten Luwu Utara.

Melalui perhitungan dengan menggunakan program SPSS 21 dapat diketahui sebagai berikut :

Tabel 7

Hasil analisis Uji $t(\alpha=0,05)$

\begin{tabular}{|l|l|c|c|c|}
\hline No. & \multicolumn{1}{|c|}{ Variabel Bebas } & $t_{\text {hitung }}$ & Probabilitas & Kesimpulan \\
\hline 1. & Kualitas Sumber Daya Manusia & 3,024 & 0,007 & Signifikan \\
\hline
\end{tabular}

Berdasarkan tabel 10 diatas dapat di ketahui pengaruh secara parsial antara variabel bebas dengan variabel terikat yaitu pengaruh variabel kualitas sumber daya manusia terhadap kinerja karyawan dapat ditunjukan pada hasil perhitungan tabel 9 diatas dimana diketahui bahwa nilai $t_{\text {hitung }}=$ 3,024 pada taraf nyata $(p=0,007<\alpha=0,05)$ atau $t_{\text {hitung }}(3,024)>t_{\text {tabel }}(2,086)$ maka $H_{0}$ ditolak dan $\mathrm{H}_{\mathrm{a}}$ diterima. Angka tersebut menunjukkan bahwa kualitas sumber daya manusia mempunyai pengaruh positif signifikan terhadap kinerja karyawan pada pengaruh yang positif dan signifikan kualitas sumber daya manusia terhadap kinerja karyawan pada TPK PNPM-MP Kecamatan Masamba Kabupaten Luwu Utara dapat diterima.

\section{SIMPULAN}

Berdasarkan hasil penelitian dan pembahasan yang telah dikemukkan pada bab sebelumnya, dapat ditarik beberapa simpulan, yaitu:

1. Secara parsial variabel kualitas sumber daya manusia berpengaruh positif dan 
signifikan terhadap kinerja karyawanpada TPK PNPM-MP Kecamatan Masamba Kabupaten Luwu Utara.Angka tersebut menunjukkan bahwanilai $t_{\text {hitung }}(3,024)>$ $t_{\text {tabel }}(2,086)$ maka hipotesisdalam penelitian ini yang menduga bahwa kualitas sumber daya manusia berpengaruh signifikan terhadap kinerja karyawan TPK PNPM-MP di Kecamatan Masamba terbukti kebenarannya atau dapat diterima.

2. Nilai koefisien regresi variabel pengembangan kualitas SDM sebesar 0,560 bernilai positif mempunyai arti bahwa jika pengembangan kualitas SDM naik sebesar satu satuan maka akan meningkatkan kinerja karyawan sebesar 0,560 atau jika persepsi terhadap kualitas sumber daya manusia semakin baik maka itu akan meningkatkan kinerja karyawan.

3. Nilai koefisien determinasi $\left(R^{2}\right)$ sebesar 0,314 , hal ini berarti bahwa $31,4 \%$ variasi dari naik turunya kinerja karyawan dapat dijelaskan olehkuaitas sumber daya manusia. Sedangkan sisanya sebesar $68,6 \%$ dipengaruhi oleh variabel lain vang tidak teranalisis dalam penelitian ir

4. Korelasi atau hubungan antara variabel kualitas sumber daya manusia dengan kinerja karyawan adalah sebesar $56,00 \%$. Artinya koefisien korelasi yang bernilai positif tersebut menunjukkan orientasi hubungan searah, dimana kualitas sumber daya manusia semakin baik, maka akan meningkatkan kinerja karyawan.

\section{SARAN}

Berdasarkan simpulan yang dikemukakan diatas, maka terdapat saran yang ditujukan untuk:

1. Bagi TPK PNPM-MP Kecamatan Masamba Kabupaten Luwu Utara untuk bisa terus mempertahankan kinerja karyawannya melalui pengambangan kualitas SDM nya misalnya memberikan kesempatan untuk mengikuti pelatihan yang terkait dengan kualifikasi pekerjaan pada TPK PNPM-MP Kecamatan Masamba Kabupaten Luwu Utara untuk mengembangkan kualitas SDM yang dimilikinya agar didalam penyelesaian setiap tugas atau pekerjaan dapat diselesaikan sesuai dengan prosedur yang ditetapkan oleh TPK PNPM-MP Kecamatan Masamba Kabupaten Luwu Utara.

2. Bagi peneliti lain yang ingin meneliti dengan topik yang mirip dengan penelitian ini hendaknya menambahkan beberapa variabel penelitan dalam mengukur kinerja karyawan, hal ini dapat dilihat dari nilai koefisien determinasi yang masih belum mendekati nilai satu, dimana nilai koefisien determinasinya yaitu sebesar $31,4 \%$.

\section{DAFTAR PUSTAKA}

A.Wawan dan Dewi M. 2010. Teori dan Pengukuran, Pengetahuan, Sikap dan Perilaku Manusia.Yogyakarta : Nuha Medika.

Aksay. 2005. Pelatihan dan Keterampilan (online) Tersedia: 
http://aksay.multiply.com/journal/item/2

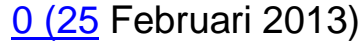

Arikunto, Suharsimi. 1993. Manjemen Penelitian. Jakarta: PT. Raja Grafindo. Persada.Bumi Aksara.

Dale, Margaret A. 2003. The Art of HRD Developing Management Skills. Meningkatkan Keterampilan Manajemen. Edisi Bahasa Indonesia. Jakarta: PT Bhuana IImu Poluler.

Fahmi,Irham. 2011. Manajemen tori,kasus dan solusi.cetakan kesatu. Bandung: ALFABETA.

Fattah, N, 2000. Landasan Manajemen Pendidikan. Bandung: Remaja Rosdakarya.

Ghozali, Imam. 2006. Aplikasi Analisis Multivariate Dengan Program SPSS. Semarang: Badan Penerbit Universitas Diponegoro.

Hasibuan, H. Malayu S.P. 2001. Manajemen Sumber Daya Manusia. Jakarta: PT Bumi Aksara.

2002. Manajemen Sumber Daya Manusia. Bumi Aksara. Jakarta.

Kotler, Phillip dan Gary Amstrong, 2001. Prinsip-Prinsip Pemasaran, jilid 2, Edisi Bahasa Indonesia. Jakarta: Penerbit Erlangga

Makmur, Syarief, 2008. Pemberdayaan Sumber Daya Manusia dan Efektivitas Organisasi. Jakarta: PT. Raja Grafindo Persada.

Mangkunegara, Anwar Prabu. 2001. Manajemen Sumber Daya Manusia Perusahaan. Bandung: Remaja Rosdakarya.

\section{Evaluasi Kinerja}

Sumber Daya Manusia. Cetakan I. Bandung: PT Refika Aditama.
Matutina. 2001. Manajemen Sumber daya Manusia. Cetakan kedua, Jakarta: Gramedia Widia Sarana Indonesia.

Notoatmodjo, Soekidjo. 2003. Pendidikan dan Prilaku Kesehatan.Jakarta : PT. Rineka Cipta.

Prawirosentono, Suyadi. 1999. Kebijakan Kinerja Karyawan. Kiat MembangunOrganisasi Kompetitif Menjelang Perdagangan Bebas Dunia. Edisi Pertama. Yogyakarta: BPFE.

Prayoto. 2004. Kualitas Sumber Daya Manusia. Majalah ilmiah UNIKOM Vol.01/01/2004

Putra Raniasa, dkk. (2005). Hubungan Kualitas Sumber Daya Manusia dan Penerapan Pola Kepemimpinan Demokrasi Pancasila Dengan Kinerja Organisasi Pada Dinas Perindustrian dan Perdagangan dan Koperasi Pengusaha Kecil Menengah Kabupaten Ogan Komering Ulu. Karya IImiah. Universitas Sriwijaya. Sumatera Selatan.

Riduwan. 2006. Metode dan Teknik Menyusun Tesis. Bandung: Alfabeta.

Rivai, Veithzal. 2005. Manajemen Sumber Daya Manusia untuk Perusahaan. Dari Teori Ke Praktik. Jakarta: PT Raja Grafindo Persada.

Robbins, Stephen P. 2000. Perilaku Organisasi. Edisi 12. Jakarta: Penerbit Salemba Empat.

2001. Perilaku Organisasi. Konsep, Kontroversi, Aplikasi. Jilid I. Edisi Kedelapan. Jakarta: Prenhallindo

Santoso Singgih. 2004. Menguasai Statistik di Era Informasi Dengan SPSS 14. Jakarta : PT. ELEX Media Computindo 
Sarwono.S.W. 2010. Psikologi Remaja. Jakarta : PT. Raja Grafindo Persada.

Sedarmayanti, 2001. Sumber Daya Manusia dan Produktivitas Kerja. Bandung: Mandar Maju,

Suliyanto. 2011. EKONOMETRIKA TERAPAN: Teori dan Aplikasi dengan SPSS. Yogyakarta: Andi.

Umam, khairul. 2010. perilaku organisasi.cetakan I . Bandung: CV PUSTAKA SETIA.

Undang-Undang Republik Indonesia Nomor 14 tahun 2005 tentang Guru dan Dosen.

Widiyanta, Ari. 2002. Sikap Terhadap Lingkungan Alam (Tinjauan Islam dalam Menyelesaikan Masalah Lingkungan). [online]. Tersedia:http://library.usu.ac.id/module s.php?op=modload $\&$ name $=$ Downloads \&file $=$ index\&req $=$ getit $\&$ lid $=115$.

Diakses 27 Maret 2013 